\title{
FORCE MAJEURE CLAUSULES DUE TO COVID-19 IN BANK CREDIT AGREEMENTS
}

\author{
Pita Permatasari \\ Departement of Law, IBLAM School of Law \\ Jalan Kramat Raya No.25, Jakarta Pusat
}

\begin{abstract}
Abstrack
Loan agreements usually contain clauses related to the rights and obligations betwen the debtor and creditor, but sometimes a force majeure clause is included if there is a situation beyond the will of the parties, such as natural disasters or war. The force majeure clause stipulated in Article 1244 and 1245 of Civil Code, in which there are for elements, first is there is an event that causes an achivement to be impossible, second is there is a cause that lies outside debtor's fault, third is the causative factor was unexpected, and forth is the incident could not be blamed on the debtor. COVID19 is considered a natioal disaster through the Presidential Decree of the Republic Indonesia Number 12 of 2020 dated April 13, 2020 concerning the Determination of the Non-Natural Disaster of The Corona Virus Desease 2019 (COVID-19) as National Disaster. Because of this, COVID-19 falls into category of relative or temporary force majeure. In addition, the government has made efforts to help the comunity, in this case UMKM actors who became debtors affected by COVID-19 by providing concessions for debtors to carry out kredit restructuring through the Finansial Services Authority Regulation Number 11/POJK.03/2020 Concerning National Economic Stmulus as Policy Countercyclical Impact of Coronavirus Disease 2019 Spread. The hope is to increase the resiliance of the debtor's business in the midst of crisi due to the COVID-19 pandemic.
\end{abstract}

Keywords: loan agreement, bank, force majeure, covid-19. 


\title{
KLAUSUL FOCE MAJEURE AKIBAT COVID-19 DALAM PERJANJIAN KREDIT BANK
}

\section{Pita Permatasari}

\author{
Program Studi Sarjana Hukum, Sekolah Tinggi Ilmu Hukum IBLAM \\ Jalan Kramat Raya No. 25 Jakarta Pusat
}

\section{Intisari}

\begin{abstract}
Perjanjian kredit biasanya memuat klausul-klausul terkait hak dan kewajiban antara debitur dan kreditur, namun terkadang dimasukkan klausul force majeure jika dikemudian hari terjadi keadaan diluar kehendak para pihak seperti bencana alam atau adanya peperangan. Klausul force majeure yang diatur dalam Pasal 1244 dan 1245 KUHPer yang mana terdapat empat unsur yaitu adanya kejadian yang menyebabkan suatu prestasi tidak mungkin dilaksanakan, ada sebab yang terletak di luar kesalahan debitur, faktor penyebab itu tidak diduga sebelumnya, dan tidak dapat dipertanggungjawabkan kepada debitur. COVID-19 telah dianggap sebagai bencana nasional melalui Keputusan Presiden Republik Indonesia Nomor 12 Tahun 2020 tanggal 13 April 2020 Tentang Penetapan Bencana Nonalam Penyebaran Corona Virus Desease 2019 (COVID-19) Sebagai Bencana Nasional. Karena hal tersebut, COVID-19 masuk kedalam kategori force majeure relatif atau sementara. Selain itu, pemerintah telah berupaya untuk membantu masyarakat dalam hal ini pelaku umkm yang menjadi debitur yang terdampak COVID-19 dengan memberikan kelonggaran kepada debitur untuk melakukan restrukturisasi kredit melalui Peraturan Otoritas Jasa Keuangan Nomor 11 /POJK.03/2020 Tentang Stimulus Perekonomian Nasional Sebagai Kebijakan Countercyclical Dampak Penyebaran Coronavirus Disease 2019. Harapannya adalah meningkatkan ketahanan bisnis debitur di tengah krisis akibat pandemi COVID-19.
\end{abstract}

Kata Kunci: Perjanjian kredit, bank, force majeure, covid-19. 


\section{A. Pendahuluan}

Presiden Joko Widodo telah menetapkan Corona Virus Desease (COVID-19) sebagai bencana nonalam melalui Keputusan Presiden Republik Indonesia Nomor 12 Tahun 2020 tanggal 13 April 2020 Tentang Penetapan Bencana Nonalam Penyebaran Corona Virus Desease 2019 (COVID-19) Sebagai Bencana Nasional. Hal ini mengguncang berbagai kalangan masyarakat di Indonesia karena kedatangan COVID19 yang mendadak ini.

World Health Organization (WHO) mencatat bahwa di Indonesia hingga tanggal 23 Januari 2021 terdapat 951.651 orang terkonfirmasi positif dan 27.203 telah meninggal dunia akibat COVID-19. ${ }^{1}$ Segala upaya dilakukan oleh pemerintah termasuk pembatasan kegiatan di luar rumah seperti yang dilakukan oleh Gubernur DKI Jakarta yang telah mengeluarkan Peraturan Gubernur Daerah Khusus Ibu Kota Jakarta Nomor 101 Tahun 2020 tanggal 9 Oktober 2020 Tentang Perubahan Atas Peraturan Gubernur Nomor 79 Tahun 2020 Tentang Penerapan Disiplin Dan Penegakan Hukum Protokol Kesehatan Sebagai Upaya Pencegahan Dan Pengendalian Corona Virus Disease 2019. Selain Gubernur DKI Jakarta, wilayah daerah lainnya menerapkan sanksi bagi pelanggar protokol kesehatan, yakni Gubernur Jawa Tengah melalui Peraturan Gubernur Jawa Tengah Nomor 33 Tahun 2020 tanggal 9 September 2020 Tentang Pengenaan Sanksi Administratif Terhadap Pelanggaran Protokol Kesehatan

1 World Health Organization, https://covid19.who.int/region/searo/country/id, diakses pada tanggal 23 Januari 2020.
Corona Virus Disease (COVID-19) Oleh Pegawai Negeri Sipil Dan Non Pegawai Negeri Sipil Di Lingkungan Pemerintah Provinsi Jawa Tengah hingga Plt. Gubernur Aceh, Nova Iriansyah pun menerbitkan Peraturan Gubernur Aceh Nomor 51 Tahun 2020 tanggal 21 November 2020 Tentang Peningkatan Penanganan Corona Virus Desease, Penerapan Disiplin dan Penegakan Hukum Protokol Kesehatan di Aceh.

Pembatasan sosial telah diterapkan, namun apakah masyarakat sudah siap akan pembatasan tersebut. Kendati demikian masyarakat tetap butuh pangan, memakai sandang, dan berlindung pada papan. Jika di luar rumah takut terkena COVD-19 sedangkan di dalam rumah takut mati kelaparan. Itulah yang dirasakan beberapa masyarakat menengah kebawah. Berbeda hal dengan masyarakat yang memiliki pendapatan tetap dengan tambahan memiliki dana darurat unuk kebutuhan hidupnya pada masa pandemi COVID-19 ini. Seperti kita rasakan bahwa COVID-19 melandaikan pergerakan ekonomi yang mengakibatkan banyak pelaku usaha melakukan efisiensi untuk menekan kerugian, seperti pengurangan gaji karyawan atau memberhentikan karyawan secara permanen. Kamar Dagang dan Industri (KADIN) mencatat 6,4 juta pekerja dirumahkan atau mengalami pemutusan hubungan kerja (PHK) akibat pandemi COVID19. Hal tersebut disebabkan karena efek dari merosotnya omzet selama pandemi. $^{2}$

\footnotetext{
2 Dian Kurniati, Kadin: 6,4 Juta Pekerja Dirumahkan atau Di-PHK Akibat Corona, DDTC.com,
} 
Jika dilihat saat masa pendemi di mulai dari Maret 2020 sampai saat ini banyak perusahaan mengalami masalah dalam bisnis. Hal tersebut karena sulitnya permodalan, produksi terhambat, penjualan atau permintaan menurun. COVID-19 berdampak besar kepada UMKM bahkan omzet menurun hingga $30 \%$ (tiga puluh persen). ${ }^{3}$

Peran pemerintah sangat dibutuhkan dalam pada masa pandemi saat ini untuk semua sektor bisnis agar masyarakat yang mengalami dan terkena dampak pandemi dapat bertahan dan bisa melewati krisis pandemi. Salah satu kebijakan pemerintah saat ini adalah adanya relaksasi pinjaman yang dan subisidi bunga yang dimana Pemerintah mengalokasikan anggaran penanganan COVID-19 serta Pemulihan Ekonomi Nasional (PEN) total Rp607,65 triliun baik bagi Usaha Mikro, Kecil, dan Menengah maupun subsidi dan relaksasi untuk Kredit Ultra Mikro (UMi). Sebanyak Rp35,28 triliun untuk 60,66 juta debitur digunakan untuk alokasi subsidi bunga UMKM terdampak pandemi COVID-19 agar usaha mereka tidak berhenti total. Pemerintah sangat peduli dengan keberlangsungan UMKM karena 90\% ekonomi Indonesia ditopang. ${ }^{4}$

Ekonomi yang tersendat tidak melenggangkan kewajiban utang piutang para pelaku usaha maupun masyarakat, namun apakah dengan adanya pandemi COVID-19 mengecualikan pembayaran akan utang

3 Cantika Adinda Putri, Sedihnya, Omzet UMKM Turun 30\% di Masa Pandemi Covid19, CNBCINDONESIA.com

4 Sekertariat Kabinet Republik Indonesia, Pemerintah Berikan Subsidi Bunga UMKM dan Relaksasi Kredit Ultra Mikro. piutang tersebut mengingat ekonomi tidak bergerak sebagaimana mestinya.

Utang piutang akan selalu berkaitan dengan istilah kreditur dan debitur yang mana sering digunakan dalam keseharian untuk melakukan transaksi bisnis bahkan dituangkan ke dalam perjanjian. Kreditur adalah pihak baik itu perorangan, perusahaan, organisasi atau pemerintah yang mana memiliki tagihan kepada pihak lain (pihak kedua) atau pihak yang memberikan kredit atau pinjaman kepada pihak lainnya.

Menurut Syamsudin M. Sinaga, terdapat 5 macam Kreditor, yakni: ${ }^{5}$

a. Kreditor Separatis, adalah Kreditor pemegang gadai, hipotik, jaminan fidusia, hak tanggungan, dan agunan atas kebendaan lainnya. Kreditor ini memiliki kedudukan paling tinggi jika dibandingkan dengan Kreditor lainnya dan dapat mengeksekusi haknya seolah-olah tidak terjadi kepailitan. (Pasal 1134 ayat (2) KUHPerdata jo. Pasal 55 UUKPKPU).

b. Kreditor Preferen, adalah Kreditor yang didahulukan pembayarannya atas semua harta pailit berdasarkan sifat piutangnya. Pembayarannya diistimewakan atas hasil penjualan barang bergerak maupun barang tetap. (Pasal 1139 dan Pasal 1149 KUHPerdata).

c. Kreditor Konkuren, adalah semua Kreditor atau penagih berdasarkan piutang tanpa ikatan tetentu. Pada Kreditor ini bersama-sama akan memperoleh pembayaran piutangnya menurut perimbangan besar kecilnya piutang. (Pasal 1132 KUHPerdata).

\footnotetext{
5 Syamsudin M. Sinaga, Hukum Kepailitan Indonesia, (Ciputat: PT Tatanusa, 2012), cet. ke-1, hal.13-15.
} 
d. Kreditor Sindikasi, adalah orang yang mempunyai piutang karena perjanjian atau undang-undang yang dapat ditagih di muka pengadilan. Masing-masing Kreditor dalam Kreditor Sindikasi berhak mengajukan permohonan pailit.

e. Kreditor Fiktif, adalah Kreditor yang tidak mempunyai dokumen resmi, namun dokumen direkayasa sedemikian rupa seolah-olah sah, sehingga menimbulkan hak suara bagi Kreditor tersebut. Hal ini bertujuan untuk mendapatkan suara resmi guna memenangkan voting pada rapat Kreditor. Padahal UUKPKPU telah menentukan kriteria dari Kreditor yang telah memiliki hak suara.

Sedangkan Debitur adalah pihak yang berhutang kepada pihak lain, biasanya dengan menerima sesuatu dari pihak lainnya (kreditur) yang dijanjikan oleh debitur untuk membayar kembali di waktu yang telah disepakati. Pemberian pinjamannya sendiri umumnya memerlukan sebuah jaminan atau agunan dari pihak debitur.

Istilah Debitur disinggung dalam Undang-Undang Nomor 10 Tahun 1998 tentang Perubahan Atas UndangUndang Nomor 7 Tahun 1992 tentang Perbankan ("UU Perbankan") yakni

Nasabah Debitur adalah nasabah yang memperoleh fasilitas kredit atau pembiayaan berdasarkan Prinsip Syariah atau yang di persamakan dengan itu berdasarkan perjanjian bank dengan nasabah yang bersangkutan.

Sedangkan Debitor dalam UndangUndang Nomor 37 Tahun 2004 Tentang Kepailitan dan Penundaan Kewajiban Pembayaran Utang ("UUKPKPU") memberikan dua definisi yakni Debitor dan Debitor Pailit yaitu: ${ }^{6}$

Debitor adalah orang yang mempunyai utang karena perjanjian atau undang-undang yang pelunasannya dapat ditagih di muka pengadilan.

Debitor pailit adalah debitor yang sudah dinyatakan pailit dengan putusan Pengadilan.

Jadi, yang membedakan Debitor dan Debitor Pailit adalah pernyataan pailit dari putusan Pengadilan Niaga. Sedangkan Kreditor diberikan definisi tersendiri oleh UUKPKPU yaitu orang yang mempunyai piutang karena perjanjian atau Undang-Undang yang dapat ditagih di muka pengadilan.

Seperti kita ketahui bahwa masyarakat maupun pelaku usaha tidak sedikit yang menjadi debitur. Bank sebagai salah satu finansial intermediary yaitu sebagai lembaga perantara keuangan. Bank memiliki fungsi menghimpun dana dari pihak yang memiliki kelebihan dana (surplus of funds) dan menyalurkannya kepada pihak yang memerlukan dana (lack of funds).

Tujuan Bank sebagai penyalur kredit menjadi jalan keluar para pelaku usaha untuk mengembangkan usahanya yaitu dengan melakukan Perjanjian Kredit. Perjanjian Kredit ini tidak serta merta dilakukan bank selaku kreditur untuk mencairkan dananya kepada para pelaku usaha maupun masyarakat. Namun, ada syarat dan ketentuan yang

\footnotetext{
6 Undang-Undang Nomor 37 Tahun 2004 Tentang Kepailitan dan Penundaan Kewajiban Pembayaran Utang, Lembaran Negara Republik Indonesia (LNRI) Tahun 2004 Nomor 131, dan Tambahan Lemabara Negara (TLN) No. 4443, Pasal 1 angka 2 adn angka 3.

7 Neni Sri Imaniyati, Pengantar Hukum Perbankan Indonesia, (Bandung: Refika Aditama, 2010), hal. 15.
} 
dterapkan setiap bank untuk menerima permohonan kredit dari calon debitur.

Munir Fuady mengutip Noan Webster 1972 bahwa kredit yang berasal dari creditus memiliki arti "kepercayaan", merupakan bentuk pats principle dari kata credere yang berarti to trust (kepercayaan). ${ }^{8}$

Maka dari itu, kredit memiliki unsur utama yakni kepercayaan. Hal tersebut memberikan arti bahwa Kreditur (pemberi kredit) memiliki kepercayaan bahwa Debitur (penerima kredit) memiliki kesanggupan untuk membayar kewajibannya sesuai yang telah diperjanjikan. Kredit sendiri ada dalam pasal 1 angka 11 UU Perbankan, yaitu:

Kredit adalah penyediaan uang atau tagihan yang dipersamakan dengan itu berdasarkan persetujuan atau kesepakatan pinjam meminjam antara bank dengan pihak lain yang menjanjikan pihak peminjam untuk melunasi hutangnya setelah jangka waktu tertentu dengan pemberian bunga.

Perjanjian Kredit menurut Hukum Perdata Indonesia adalah salah satu dari bentuk perjanjian pinjam meminjam sebagaimana diatur dalam Pasal 1754 sampai dengan Pasal 1769 KUHPerdata. Dalam praktek, bentuk dan materi perjanjian kredit antara satu bank dengan bank yang lainnya tidaklah sama disesuakkan dengan kebutuhannya masing-masing. Dengan demikian, perjanjian kredit tersebut tidak mempunyai bentuk tertentu, hanya saja dalam praktek ada banyak hal yang biasanya dicantumkan dalam perjanjian kredit, misalnya definisi istilah-istilah yang akan dipakai dalam

8 Munir Fuady, Hukum Perkreditan Kontemporer, (Bandung: Citra Aditya Bakti, 1996), hal. 5. perjanjian terutama dalam perjanjian kredit dengan pihak asing atau dikenal dengan loan agreement, jumlah dan batas waktu pinjaman, serta pembayaran kembali pinjaman (repayment) juga mengenal apakah si peminjam berhak mengembalikan dana pinjaman lebih cepat dari ketentuan yang ada, penetapan bunga pinjaman dan dendanya bila debitur lalai membayar bunga, terakhir dicantumkan berbagai klausul seperi hukum yang berlaku untuk perjanjian tersebut. Klausul lainya adalah force majeure.

Klausul force majeure atau keadaan kahar dibuat oleh para pihak perjanjian untuk megantisipasi kejadian yang tidak terduga. Rahmat S.S. Soemadipradja memberikan defisini yang diambil dari beberapa para ahli bahwa keadaan memaksa adalah suatu keadaan di mana salah satu pihak dalam suatu perikatan tidak dapat memenuhi seluruh atau sebagian kewajibannya sesuai apa yang diperjanjikan, disebabkan adanya suatu peristiwa di luar kendali salah satu pihak yang tidak dapat diketahui atau tidak dapat diduga akan terjadi pada waktu membuat perikatan, di mana pihak yang tidak memenuhi kewajibannya ini tidak dapat dipersalahkan dan tidak harus menanggung risiko. ${ }^{10}$

Melihat kesulitan masyarakat dan pelaku usaha menghadapi pandemi COVID-19 hingga akhirnya berdampak kepada pembayaran utang piutang yang mereka miliki. Namun apakah pandemi COVID-19 dpaat dikategorikan sebagai

\footnotetext{
${ }^{9}$ Muhamad Djumhana, Hukum Perbankan di Indonesia, (Bandung: Citra Aditya Bakti, 1996), cet. ke-2 hal. 240-241.

10 Rachmat S.S. Soemadipradja, Penjelasan Hukum Tentang Keadaan Memaksa, (Jakarta: National Legal Reform Program, 2010), hal. 8.
} 
foce majeur sehingga masyarakat dan pelaku usaha yang memiliki utang di Bank memiliki keringan pembayaran atau bahkan dihapuskannya utang. Maka dari itu, penulis meneliti perihal klausul foce majeur akibat COVID-19 dalam Perjanjian Kredit Bank dengan rumusan masalah sebagai berikut:

1. Apa yang dimaksud klausul foce majeur dalam Perjanjian?

2. Apakah pandemi COVID-19 masuk kategori klausul foce majeur dalam Perjanjian Kredit Bank?

\section{B. Metode Penelitian}

Penelitian ini merupakan Penelitian Normatif, yaitu penelitian dengan menarik asas hukum, meneliti subyek hukum, hak dan kewajiban, peristiwa hukum, hubungan hukum dan objek hukum, serta mensinkronisasi suatu peraturan perundang-undangan, memperbandingkan hukum dan meneliti sejarah hukum. ${ }^{11}$ Penelitian yang saya lakukan adalah penelitian secara yuridis normatif, yakni dengan pendekatan perundang-undang yang kami gunakan untuk menelaah perihal klausul foce majeur akibat COVID-19 dalam perjanjian kredit bank.

Tipe penelitian hukum yang dilakukan adalah yuridis normatif dengan pertimbangan bahwa titik tolak penelitian analisis terhadap peraturan perundang-undangan perihal klausul foce majeur akibat COVID-19 dalam perjanjian kredit bank. Dengan mengacu pada tipologi penelitian deskriptif analitis. ${ }^{12}$

${ }^{11}$ Sri Mamudji et al. Metode Penelitian dan Penulisan Hukum, cet. 1, (Jakarta: Badan Penerbit Fakultas Hukum Universitas Indonesia, 2006), hlm. 9-11.

12 Johny Ibrahim, Teori \& Metodologi Penelitian Hukum Normatif, (Surabaya:

\section{Hasil dan Pembahasan}

Force Majeure dalam Perjanjian

Perjanjian diatur dalam buku ketiga Kitab Undang-Undang Hukum Perdata (KUHPerdata). Pasal 1233 KUHPerdata mengatakan bahwa tiaptiap perikatan dilahirkan, baik karena persetujuan,baik karena undangundang. Menurut Prof. Mariam Darus Badrulzaman bahwa perikatan adalah hubungan hukum yang terjadi di antara 2 (dua) orang atau lebih, yang terletak di dalam lapangan harta kekayaan, di mana pihak yang satu berhak atas prestasi dan pihak lainnya wajib memenuhi prestasi itu. ${ }^{13}$ Perjanjian adalah suatu perbuatan dengan mana satu orang atau lebih mengikatkan dirinya terhadap satu orang lain atau lebih. Hal ini tercantum dalam Pasal 1313 KUHPerdata. Adapun subjek perjanjian adalah pihak-pihak yang disebutkan dalam perjanjian dan terkait perjanjian.

Pasal $1320 \quad$ KUHPerdata memberikan unsur-unsur yang menjadi syarat sah perjanjian, yaitu:

1. Sepakat mereka yang mengikatkan diri;

2. Cakap untuk membuat suatu perikatan;

3. Suatu hal tertentu;

4. Suatu sebab yang halal

Syarat pertama dan kedua disebut syarat subjektif karena kedua syarat tersebut mengenai subjek perjanjian. Jika salah satu syarat subjektif tidak terpenuhi, maka salah satu pihak dapat memintakan pembatalan seperti

Bayumedia Publishing,2007), cet. Ke-3, hal.295.

${ }^{13}$ Mariam Darus Badrulzaman et.al, Kompilasi Hukum Perikatan, Bandung: PT. Citra Aditya Bakti, 2001,hal. 1 
tertuang dalam Pasal 1331

KUHPerdatadata yang mengatakan:

Karena itu orang-orang yang di dalam pasal yang lalu dinyatakan tak cakap, boleh menuntut pembatalan perikatan-perikatan yang mereka telah perbuat, dalam hal-hal di mana kekuasaan itu tidak dikecualikan dalam undang-undang.

Orang-orang yang cakap untuk mengikatkan diri tidak sekali-kali diperkenankan mengemukakan ketidakcakapan orang-orang yang belum dewasa, orang-orang yang ditaruh di bawah pengampunan dan perempuan-perempuan yang bersuami dengan siapa mereka telah membuat suatu persetujuan.

Selanjutnya, Syarat ketiga dan keempat dalam Syarat Sah Perjanjian, yaitu Suatu Hal Tertentu dan Sebab yang Halal termasuk ke dalam Syarat Objektif. Suatu perjanjian haruslah mempunyai objek (bepaald onderwerp) tertentu, sekurang-kurangnya objek tertentu itu dapat berupa benda yang sekarang ada dan nanti akan ada. (Pasal 1332, Pasal 1333, Pasal 1334 KUHPerdatadata). Perjanjian tanpa causa (Pasal 1335 KUHPerdatadata), Sebab yang halal (Pasal 136 KUHPerdatadata), Sebab terlarag (Pasal 1337 KUHPerdatadata). Tujuan perjanjian itu dapat dilaksanakan jika isi perjanjian tidak bertentangan dengan undang-undang, ketertiban umum, dan kesusilaan. Perjanjian yang cacat objektif batal demi hukum.

Perjanjian di Indonesia memiliki klasul-klausul tersendiri sesuai dengan kebutuhan masing-masing dari para pihak yang membuatnya. Adapun jenisjenis perjanjian adalah sebagai
berikut: $^{14}$

1. Perjanjian Timbal Balik
Perjanjian timbal balik adalah perjanjian yang menimbulkan kewajiban diantara para pihak. Perjanjian timbal balik ini biasa terjadi ketika para pihak membuat kesepakatan mengenai juall-beli, sewa menyewa, atau perjanjian lainnya yang timbulnya kewajiban pokok bagi para pihak.

2. Perjanjian Cuma-Cuma

Perjanjian Cuma-Cuma ini tercantum dalam Pasal 1314 KUHPerdata:

Suatu persetujuan dibuat dengan Cuma-Cuma atau atas beban. Suatu persetujuan dengan Cuma-Cuma adalah suatu persetujuan dengan mana pihak satu memberikan suatu keuntungan kepada, pihak yang lain, tanpa menerima suatu manfaat bagi dirinya sendiri...

Perjanjian Cuma-Cuma maksudnya adalah perjanjian yang memberkan keuntungan bagi salah satu pihak saja, contohnya hibah.

3. Perjanjian Atas Beban

Pasal 1314 KUHPerdata pun memberikan definisi mengena perjanjian atas beban:

...Suatu persetujuan atas beban, adalah suatu pesetujua yang mewajibkan masing-masing phak memberikan sesuatu, berbuat sesuatu, atau tidak berbuat sesuatu.

Prof. Mariam Badruldzaman mengatakan bahwa perjanjian atas beban adalah perjanjian dimana terhadap prestasi dari pihak yang satu selalu terdapat kontra prestasi dari pihak lain,

${ }^{14}$ Ibid, hal. 66-69. 
dan antara kedua prestasi itu ada hubungannya menurut hukum. ${ }^{15}$

4. Perjanjian Bernama (Benoemd)

Perjanjian bernama atau khusus adalah perjanjian yang mempunyai nama sendiri. Perjanjian-perjanjian bernama ini diatur dan diberi nama oleh pembentuk undang-undang, berdasarkan tipe yang paling banyak terjadi sehari-hari. Perjanjian khusus ini terdapat dalam Bab $\mathrm{V}$ sampai dengan Bab XVIII KUHPerdata, yaitu mengenai jual-beli, tukarmenukar, sewa-menyewa, perjanjian-perjanjian untuk melakukan pekerjaan, pesekutuan, perkumpulan, hibah, penitipan barang, pinjampakai, pinjam-meminjam, bunga tetap atau bunga abadi, perjanjian-perjanjian untunguntungan, pemberian kuasa, penanggungan, dan perdamaian. $^{16}$

5. Perjanjian Tidak Bernama (Onbenoemde Overeenkomst)

Perjanjian Tidak Bernama ini diluar Perjanjian Bernama, maksudnya adalah perjanjianperjanjian yang tidak diatur didalam KUHPerdata tetapi terdapat didalam masyarakat. Jumlah perjanjian ini tidak terbatas dengan nama yang disesuaikan dengan kebutuhan para pihak yang mengadakan perjanjian, seperti perjanjian kerja sama, perjanjian pemasaran, atau perjanjian

${ }^{15}$ Ibid, hal. 67.

16 Kitab Undang-Undang Hukum Perdata (Burgerlijk Wetboek), diterjemahkan oleh R. Subekti dan R. Tjitrosudibio, (Jakarta: PT Pranadya Paramita, 2004), cet. ke-34. pengelolaan. Perjanjian ini lahir dalam masyarakat karena dasar dari asas perjanjian itu sendiri yaitu asas kebebasan berkontrak, mengadakan perjanjian atau pertij otonomi.

6. Perjanjian Obligatoir

Perjanjian obligatoir adalah perjanjian dimana pihak-pihak sepakat mengikatkan diri untuk melakukan penyerahan suatu benda kepada pihak lain. Menurut KUHPerdata perjanjian jual beli saja belum lagi mengakibatkan beralihnya hak milik atas suatu benda dari penjual kepada pembeli. Fase ini baru merupakan kesepakatan (konsensual) dan harus diikuti dengan perjanjian penyerahan (perjanjiaan kebendaan).

7. Perjanjian Kebendaan (Zakelijk) Perjanjian kebendaan adalah perjanjian dengan nama seseorang menyerahkan haknya atas sesuatu beda kepada pihak lain, yang membebankan kewajiban (oblige) pihak itu untuk menyerahkan benda tersebut kepada pihak lain (levering, transfer). Penyerahannya itu sendiri merupakan perjanjian kebendaan. Dalam hal perjanjian jual beli benda tetap, maka perjanjian jual belinya disebutkan juga perjanjian jual beli sementara (voorkoping koopcontract). Untuk perjanjian jual beli benda-benda bergerak maka perjanjian obligatoir dan perjanjian kebendaannya jatuh bersamaan.

8. Perjanjian Konsensual

Perjanjan konsensual adalah perjanjian dimana diantara dua 
pihak telah tercapai persesuaian kehendak untuk mengadakan perikatan. Pasal 1338 KUHPerdata mengatakan bahwa perjanjia ini sudah mempunyai kekuatan mengikat.

9. Perjanjian Riil

KUHPerdata memiliki perjanjian-perjanjian yang hanya berlaku sesuai terjadi penyerahan barang, misalnya perjanjian penitipan barang seperti yang tertuang dalam Pasal 1694 KUHPerdata atau perjanjian pinjam pakai yang tertuang dalam Pasal 1740 KUHPerdata. Perbedaan antara perjanjian konsensual dan riil ini adalah sisa dari hukum Romawi yang untuk perjanjianperjanjian tertentu diambil alih oleh Hukum Perdata kita.

10. Perjanjian Liberatoir

Perjanjian ini dimana para pihak membebaskan diri dari kewajiban yang ada, misalnya pembebasan utang (kwitschelding) yang tertuang dalam Pasal 1438 KUHPerdata.

11. Perjanjian Pembuktian (Bewijsovereenkomst)

Perjanjian ini dimana para pihak menentukan pembuktian apakah yang berlaku diantara mereka.

12. Perjanjian Untung-Untungan

Perjanjian untung-untungan adalah perjanjian yang objeknya ditentukan kemudian, misalnya perjanjian asuransi yang tertuang dalam Pasal 1774 KUHPerdata.

13. Perjanjian Publik

Perjanjian publik yaitu perjanjian yang sebagian atau seluruhnya dikuasai oleh hukum publik, karena salah satu pihak yang bertindak adalah pemerintah, dan pihak lainnya swasta. Diantara keduanya terdapat hubungan atasan dan bawahan (subordinated), jadi tidak berada dalam kedudukan yang sama (co-ordinated), misalnya perjanjian ikatan dinas.

14. Perjanjian Campuran (Contractus Sui Generis)

Perjanjian campuran adalah perjanjian yang mengandung berbagai unsur perjanijian, misalnya pemiik hotel yang menyewakan kamar (adanya perjanjian sewa-menyewa) tapi pula menyajikan makanan (adanya perjanjian jual beli) dan juga memberikan pelayanan.

Adanya asas kebebasan berkontrak dalam perjanjian membolehkan para pihak bebas membuat klausul-klausul dalam perjanjian selama tidak bertentangan dengan syarat sah perjanjian sesuai dengan Pasal 1320 KUHPerdata. ${ }^{17}$ Salah satu klausul yang tercantum dalam perjanjian adalah klausul Keadaan Memaksa atau Force Majeure. Force majeure tidak memiliki undang-undang tersendiri, namun terdapat dalam ketentuan-ketentuan KUHPerdata yang mengatur ganti rugi. Pasal 1244 KUHPerdata mengatakan bahwa jika ada alasan untuk itu, si berutang (debitur), harus dihukum mengganti biaya rugi dan bunga apabila ia tidak dapat membuktikan, bahwa hal tidak atau tidak pada waktu yang tepat dilaksanakannya perikatan itu, disebabkan karena suatu hal yang tidak terduga pun tidak dapat dipertanggungjawabkan padanya, kesemuanya itu pun jika itikad buruk tidaklah ada pada pihaknya. Kemudian

${ }^{17}$ Op.Cit, hal. 84. 
Pasal 1245 mengatakan bahwa tidaklah biaya rugi dan bunga harus digantinya, apabila lantaran suatu kejadian tak disengaja si berutang (debur beralangan memberikan atau berbuat sesuatu yang diwajibkan, atau lantaran hal-hal yang sama telah melakukan perbuatan yang terlarang. ${ }^{18}$

Dari kedua pasal tersebut kita bisa lihat bahwa ada 4 (empat) unsur yang harus dipenuhi dalam keadaan memaksa yaitu:

1. Adanya kejadian yang menyebabkan suatu prestasi tidak mungkin dilaksanakan;

2. ada sebab yang terletak di luar kesalahan debitur;

3. faktor penyebab itu tidak diduga sebelumnya; dan

4. tidak dapat dipertanggungjawabkan kepada debitur.

Jika kita telaah lebih lanjut bahwa keadaan memaksa memiliki unsur "adanya hal yang tidak terduga dan tidak dapat dipertanggungjawabkan" kepada seseorang. Sedangkan yang berutang atau debitur dengan segala daya berusaha secara patut memenuhi kewajibannya. Dengan demikian hanya debiturlah yang dapat mengemukakan adanya keadaan memaksa, apabila setelah dibuat suatu perjanjian, timbul suatu keadaan yang tidak dapat didugaduga akan terjadi, dan keadaan itu tidak dapat kepadanya. ${ }^{19}$

dipertanggungjawabkan

Ada beberapa akibat dari Force Majeure dalam perikatan yang dibuat oleh para pihak karena Force Majeure mengakibatkan perikatan tersebut tidak

18 Kitab Undang-Undang Hukum Perdata, Op.cit, hal. 324-325.

${ }^{19}$ Mariam Darus Badrulzaman, KUH Perdata Buku III Hukum Perikatan dengan Penjelasan, (Bandung: PT Alumni, 2011), hal. 35-36. lagi bekerja (weking) walaupun perikatannya sendiri tetap ada. Karena hal tersebut maka: ${ }^{20}$

1. kreditur tidak dapat menuntut agar perikatan itu dipenuhi;

2. tidak dapat mengatakan debitur berada dalam keadaan lalai dan karena itu tidak dpat menuntut;

3. kreditur tidak dapat meminta pemutusan perjanjian;

4. pada perjanjian timbal balik, maka gugur kewajiban untuk melakukan kontrasepsi.

Jadi, pada asasnya perikatan itu tetap ada namun daya kerjanya hilang dan sifat dari keadaan memaksa atau force majeure adalah sementara. Perikatan itu kembali mempunyai daya kerja ketika force majeure itu berhenti.

Keadaan memaksa atau force majeure ada yang bersifat mutlak (absoluut) yaitu dalam halnya sama sekali tidak mungkin lagi melaksanakan perjanjiannya, misalnya barangnya sudah hapus karena bencana alam. Yang kedua Force Majeure yang bersifat tidak mutlak (relatief), yaitu berupa suatu keadaan dimana perjanjian masi dapat juga dilaksanakan, tetapi dengan pengorbanan-pengorbanan yang sangat besar dari hak si berutang (debitur). Subekti memberikan contoh misalnya harga barang yang masih didatangkan oleh penjual tiba-tiba harganya sangat tinggi atau dengan tiba-tiba oleh Pemerintah dikeluarkan suatu peraturan yang melarang dengan ancaman hukuman untuk mengeluarkan suatu macam barang dari suatu daerah yang menyebabkan debitur tidak dapat mengirimkan barang kepada kreditur. ${ }^{21}$

\footnotetext{
${ }^{20}$ Ibid, hal. 36.

21 Subekti, Pokok-Pokok Hukum Perdata, (Jakarta: Intermasa, 2003), hal. 150-151.
} 


\author{
Sedangkan Mariam Darus \\ Badrulzaman ${ }^{22}$ membagi 2 (dua) \\ bentuk keadaan memaksa atau force \\ majeure, yaitu: \\ 1. Bentuk Umum \\ Keadaan memaksa atau force \\ majeure bentuk umum \\ diantaranya:
a. Keadaan iklim;
b. Kehilangan;
c. Pencurian.

2. Bentuk Khusus

Sedangkan keadaan memaksa atau force majeure bentuk khusus adalah sebagai berikut:

a. Undang-undang atau Peraturan Pemerintah

Undang-undang atau Peraturan Pemerintah adakalanya menimbulkan keadaan memaksa. Dalam hal ini tidak berarti bahwa prestasi itu tidak dapat dilakukan, tetapi prestasi itu tidak boleh dilakukan akibat adanya undang-undang atau peraturan pemerintah.

b. Sumpah

Adanya sumpah terkadang menimbulkan keadaan memaksa atau force majeure, yaitu apabila seseorang yang harus berprestasi itu dipaksa bersumpah untuk tidak melakukan prestasi.

c. Tingkah laku pihak ketiga

d. Pemogokan

Bentuk-bentuk khusus tersebut adakalanya menimbulkan force majeure, adakalanya tidak.

Undang-Undang Nomor 2 Tahun 2017 Tentang Jasa Konstruksi ${ }^{23}$

\footnotetext{
${ }^{22}$ Mariam Darus Badrulzaman, Op.Cit, hal. 3839.

23 Undang-Undang Nomor 2 Tahun 2017 Tentang Jasa Konstruksi, Lembaran Negara
}

memberikan cakupan terkait keadaan memaksa yaitu:

1. keadaan memaksa yang bersifat mutlak (absolut) yakni bahwa para pihak tidak mungin melaksanakan hak dan kewajibannya; dan

2. keadaan memaksa yang bersifat tidak mutlak (relatif) yakni bahwa para pihak masih dimungkinkan untuk melaksanakan hak dan kewajibannya. $^{24}$

Peraturan Presiden Nomor 16 Tahun 2018 tentang Pengadaan Barang/Jasa Pemerintah, dalam lampirannya memberikan definisi mengenai keadaan kahar sebagai suatu keadaan yang terjadi di luar kehendak para pihak dalam kontrak dan tidak dapat diperkirakan sebelumnya, sehingga kewajiban yang diitentukan dalam kontrak menjadi tidak dapat dipenuhi. ${ }^{25}$ Ada beberapa situasi yang yang diperbolehkan jika terjadi keadaan kahar, yaitu: ${ }^{26}$

1. Dalam hal terjadi keadaan kahar, pelaksanaan kontrak dapat dihentikan;

2. Dalam hal pelaksanaan kontrak dilanjutkan, para pihak dapat melakukan perubahan kontrak;

3. Perpanjangan waktu untuk penyelesaian kontrak disebabkan keadaan kahar dapat melewati tahun anggaran;

Republik Indonesia (LNRI) Tahun 2017 No. 11. Tambahan Lembaran Negara (TLN) No. 6018., Penjelasan Pasal 47 ayat (1) huruf j.

${ }^{24}$ Ibid

25 Peraturan Presiden Nomor 16 Tahun 2018 Tentang Pengadaan Barang/Jasa Pemerintah, Lembaran Negara Republik Indonesia (LNRI)Tahun 2018 Nomor 33, Penjelasan Pasal 1 angka 52.

${ }^{26}$ Ibid, Pasal 55. 
4. Tindak lanjut setelah terjadinya keadaan kahar debitur dalam kontrak.

Di Inggris Force Majeure berikan arti sebagai berikut:

Force Majeuree events are usually defined as certain acts, events or circumstances beyond the control of the parties, for example, natural disasters or the outbreak of hostilities. A force majeureee clause typically excuses one or both parties from performance of the contract in some way following the occurrence of such events. Its underlying principle is that on the occurrence of certain events which are outside a party's control, that party is excused from, or entitled to suspend performance of all or part of its obligations. That party will not be liable for its failure to perform the obligations, in accordance with the clause. $^{27}$

Jika diartikan secara bebas bahwa Force Majeure adalah keadaan atau situasi diluar kontrol para pihak dalam perjanjian, contohnya bencana alam atau pecahnya permusuhan. Klausul Force Majeure biasanya dibuat untuk membebaskan salah satu atau kedua belah pihak untuk melaksanakan kewajiban yang telah dituangkan dalam perjanjian setelah terjadinya peristiwa tertentu. Prinsip yang mendasarinya adalah jika terjadi peristiwa tertentu yang berada diluar kendali salah satu pihak, maka pihak tersebut dibebaskan atau berhak ditangguhkan pelaksanaannya baik sebagian maupun keseluruhan kewajibannya. Pihak tersebut tidak akan bertanggung jawab untuk melaksanakan kewajibannya, sesuai dengan klausul perjanjian.

Dalam transaksi bisnis
internasional para pihak dapat

${ }^{27}$ Thomson Reuters menyetujui ketentuan dalam klausul Force Majeure. Hal ini adanya prinsip dasar hukum kontrak yang disebut dengan "kebebasan berkontrak" yang mana dapat disesuaikan oleh para pihak dengan syarat tidak bertentangan dengan undang-undang. Oleh karena itu, para pihak bebas untuk menentukan Force Majeure dengan memperluas daftar kejadian yang dianggap sebagai keadaan memaksa atau Force Majeure di yurisdiksi masing-masing, atau dengan membatasi peristiwa Force Majeure yang biasa diterima. ${ }^{28}$

\section{Klausul Force Majeure akibat COVID-19 dalam Perjanjian Kredit Bank}

Kegiatan pemberian kredit merupakan kegiatan yang sangat pokok dan sangat konvensional dai suatu bank bahkan ahli mengatakan bahwa fungsi tradisional bank adalah menghimpun dana dari masyarakat dan meyalurkan dana kepada masyarakat. Penyaluran dana pada umumnya dilakukan dalam bentuk pemberian kredit. ${ }^{29}$

Kredit pada perkembangannya mengarahkan fungsinya untuk merangsang bagi kedua belah pihak yakni bank dan debitur untuk saling menolong dengan tujuan pencapaian kebutuhan baik dalam bidang usaha maupun kebutuhan sehari-hari. Pihak yang mendapatkan kredit harus dapat menunjukkan prestasi yang lebih tinggi dari kemajuan usahanya itu sendiri atau mendapatkan pemenuhannya. Adapun bagi pihak yang memberi kredit, secara material dia harus mendapatkan

\footnotetext{
28 Hubert Konarski, Force Majeuree and Hardship Clauses in Internasional Contractual Practice, (No 4 of 2003 Int'l Bus. L. J. 405 428, 2003).

${ }^{29}$ Neni Sri Imaniyati, Op.Cit, hal. 139.
} 
rentabilitas berdasarkan perhitungan yang wajar dari modal yang dijadikan objek kredit, dan secara spiritual mendapatkan kepuasan dengan dapat membantu pihak lain untuk mendapat kemajuan. $^{30}$

Sebelum bank dan calon debitur menandatangani perjanjian kredit, para pihak akan mengadakan suatu perundingan yang menyangkut klausulklausul yang perlu dicantumkan dalam perjanjian kredit tersebut. Menurut $\mathrm{Ch}$. Gatot Wardoyo dalam buku Djumhana bahwa ada beberapa klausul yang selalu, dan dicantumkan dalam setiap perjanjian kredit, yaitu: ${ }^{31}$

1. Syarat-syarat penarikan kredit pertama kali (predisbursetment clause)

Klausul ini menyangkut mengenai:

a. Pembayaran provisi, premi asuransi kredit, dan asuransi barang jamian serta biaya pengikatan jaminan secara lunas;

b. Penyerahan barang jaminan, dan dokumennya serta pelaksanaan pengikatan barang jaminan tersebut;

c. Pelaksanaan penutupan asuransi barang jaminan, dan asuransi kredit dengan tujuan untuk memperkecil risiko yang terjadi di luar kesalahan debitur maupun kreditur.

2. Klausul mengenai maksimum kredit (amount clause)

Klausul ini mempunyai arti penting dalam beberapa hal, yaitu:

a. Merupakan objek dari perjanjian kredit sehingga perubahan kesepakatan

${ }^{30}$ Djumhana, Op.Cit, hal. 232.

${ }^{31}$ Ibid, hal. 242-246. mengenai materi ini menimbulkan konsekuensi diperlukannya pembuatan perjanjian kredit baru (sesuai dengan Pasal 1381 butir 3 dan Pasal 1413 KUHPerdata Novasi Objektif);

b. Merupakan batas kewajiban pihak kreditur yang berupa penyediaan dana selama tenggang waktu perjanjian kredit, yang berarti pula batas hak debitur untuk melakukan penarikan pinjaman;

c. Merupakan penetapan besarnya nilai agunan yang harus diserahkan, dasar perhitungan penetapan besarnya provisi atau commitment fee;

d. Merupakan batas dikenakannya denda kelebihan tarik (over-draft).

3. Klausul mengenai jangka waktu kredit

Klausul ini penting karena:

a. Merupakan batas waktu bagi bank kapan keharusan menyediakan dana sebesar maksimum kredit berakhir dan sesudah dilewatinya jangka waktu ini sehingga menimbulkan hak tagih/pengembalian kredit dari nasabah;

b. Merupakan batas waktu kapan boleh melakukan teguranteguran kepada debitur apabila tidak memenuhi kewajiban tepat pada waktunya;

c. Merupakan suatu masa yang tepat wabgi bank untuk melakukan review, atau analisis kembali apakah fasilitas kredit tersebut perlu 
diperpanjang atau perlu segera ditagih kembali.

4. Klausul mengenai bunga pinjaman

Klausul ini diatur secara tegas dalam perjanjian kredit dengan maksud untuk:

a. Memberikan kepastian mengenai hak bank untuk memungut bunga pinjaman dengan jumlah yang sudah disepakati bersama karena bunga merupakan penghasilan bank yang baik secara langsung maupun tidak langsung akan diperhitungkan dengan biaya dana untuk penyediaan fasilitas kredit tersebut;

b. Pengesahan pemungutan bunga di atas $6 \%$ per tahun Hal tersebut mengacu pada keterangan Pasal 1765 dan Pasal 1767 KUHPerdata yang memberikan pemungutan bunga pinjaman di atas $6 \%$ per tahun asalkan diperjanjikan secara tertulis.

Saat ini, Otoritas Jasa Keuangan (OJK) mendapatkan laporan dari bank yang terdaftar dan diawasi oleh OJK secara online melalui Aplikasi Online OJK (APOLO), dengan keterangan sebagai berikut: ${ }^{32}$

1. Suku Bunga Dasar Kredit (SBDK) digunakan sebagai dasar penetapan suku bunga kredit yang akan dikenakan oleh bank kepada nasabah. SBDK belum memperhitungkan komponen estimasi premi risiko yang besarnya tergantung dari penilaian

${ }^{32}$ Otoritas Jasa Keuangan bank terhadap risiko masing-masing debitur atau kelompok debitur. Dengan demikian, besarnya suku bunga kredit yang dikenakan kepada debitur belum tentu sama dengan SBDK.

2. Dalam kredit konsumsi nonKPR tidak termasuk penyaluran dana melalui kartu kredit dan Kredit Tanpa Agunan (KTA).

3. Informasi SBDK yang berlaku setiap saat dapat dilihat pada publikasi di setiap kantor bank dan/atau situs web Bank.

5. Klausul mengenai barang agunan kredit

Klausul ini bertujuan agar pihak debtur tidak melakukan penarikan atau penggantian barang jamian secara sepihak, tetapi harus ada kesepakatan dengan pihak bank.

6. Klausul asuransi (insurance clause)

Klausul ini bertujuan untuk pengalihan risiko yang mungkin terjadi baik atas barang agunan maupun atas kreditnya sendiri. Adapun materinya perlu memuat mengenai maskapai asuransi yang ditunjuk, premi asuransinya, keharusan polis asuransi untuk disimpan di bank, dan sebagainya.

7. Klausul mengenai tindakan yang dilarang oleh bank (negative clause)

Klausul ini terdiri atas berbagai macam hal yang mempunyai akibat yuridis dan ekonomi bagi pengamanan kepentingan bank sebaga tujuan utama. Adapaun contoh tindakan yang tidak 
diperkenankan dilakukan debitur diantaranya adalah:

a. Larangan meminta kredit kepada pihak lain tanpa seizin bank;

b. Larangan mengubah bentuk hukum perusahan debitur tanpa seizin bank;

c. Larangan membubarkan perusahaan tanpa seizin bank; ${ }^{33}$

8. Tigger Clause atau Opeisbaar Clause

Klausul ini mengatur hak bank untuk mengakhiri perjanjian kredit secara sepihak walaupun jangka waktu perjanjian kredit tersebut belum berakhir.

9. Klausul mengenai denda (penalty clause)

Klausul ini dimaksudkan untuk mempertegas hak-hak bank untuk melakukan pungutan baik mengenai besarnya maupun kondisinya.

10. Expense Clause

Klausul ini mengatur mengenai beban biaya dan ongkos yang timbul akibat pemberian kredit, yang biasanya dibebankan kepada nasabah, dan meliputi antara lain, biaya pengikatan jaminan, pembuatan akta-akta perjanjian kredit, pengakuan hutang, dan penagihan kredit.

11. Debet Authorization Clause Pendebetan rekening pinjaman debitur haruslah dengan izin debitur.

12. Representation and Warranties Klausul ini sering juga disebut dengan istilah material adverse change clause. Maksudnya adalah bahwa pihak debitur menjanjikan dan menjamin dan semua data dan informasi yang diberikan kepada bank adalah benar dan tidak diputarbalikan.

13. Klausul ketaatan pada ketentuan bank

Klausul ini dimaksudkan untuk menjaga kemungkinan bila terdapat hal-hal yang tidak diperjanjikan secara khusus tetapi dipandang perlu, maka sudah dianggap telah diperjanjikan secara umum. Misalnya, mengenai masalah tempat dan waktu melakukan pencairan dan penyetoran kredit, penggunaan formulir, format surat, konfirmasi atau pemberitahuan saldo rekening bulanan.

14. Miscellaneous atau Boiler Plate Provision

Pasal-pasal tambahan.

15. Dispute Settlement (Alternative Dispute Resolution)

Klausul ini mengenai metode penyelesaian perselisihan antara kreditur dengan debitur (bila terjadi dikemudian hari).

16. Pasal penutup

Pasal penutup memuat eksemplar perjanjian kredit yang maksudnya mengadakan pengaturan mengenai jumlah alat bukti dan tanggal mulai berlakunya perjanjian kredit.

Klausul lainnya yang biasa ada dalam perjanjian kredit adalah klausul keadaan kahar atau force majeure. Jika dilihat empat unsur force majeure dalam Pasal 1244 dan Pasal 1245 KUHPerdata khawatir akan menimbulkan multitafsir dan berpotensi sengketa para pihak dikemudian hari. Maka demi kepastian hukum, maka para pihak pada umumnya mencantumkan klausula

${ }^{33}$ Ibid 
mengenai force majeure dalam perjanjiannya, seperti: ${ }^{34}$

a. Act of God (such as, but not limited to fires, explosions, earthquakes, drought, tidal waves and floods);

b. War, hostilities (whether war be declared or not), invasion, act of foreign enemies, mobilization, requisition, or embargo;

c. Rebellion, revolution, insurrection, or military or usurped power, or civil war;

d. Contamination by radio-activity from any nuclear fuel, or from any nuclear waste from the combustion of nuclear fuel, radio-active toxic explosive, or other hazardous properties of any explosive nuclear assembly or nuclear component of such assembly;

e. Riot, commotion, strikes, go slows, lock outs or disorder, unless solely restricted to employees of the Supplier;

f. Acts or threats of terrorism; or

g. Other unforeseeable circumstances beyond the control of the Parties against which it would have been unreasonable for the affected party to take precautions an which the affected party cannot avoid event by using best efforts.

Direktorat Jenderal Pajak mengeluarkan peraturan dengan Keputusan Direktur Jenderal Pajak Nomor KEP-178/PJ/2020 Tentang Perpanjangan Jangka Waktu Penyelesaian Pelayanan Administrasi

\footnotetext{
34 E. Agtha dan A.Novera, Keadaan Kahar Akibat COVID-19 dan Penerapannya dalam Perjanjian Kredit, Seminar Nasional AvoER XII 2020 Fakultas Teknik Universitas Sriwijaya.
}

Perpajakan dalam Keadaan Kahar Akibat Pandemi Coronavirus Disease 2019. Dalam Keputusan tersebut mengatakan bahwa keadaan tertentu darurat bencana akibat penyebaran COVID-19 sebagai keadaan kahar (force majeure). ${ }^{35}$

Sedangkan unsur force majeure akibat COVID-19 yang tertuang dalam Pasal 1244 dan 1245 KUHPerdata adalah sebagai berikut:

1. Adanya kejadian yang tidak terduga

COVID-19 pertama kalli terdeteksi di Wuhan, China pada tanggal 31 Desember 2019 yang diterima dalam laporan WHO. Lalu tanggal 29 Februari 2020 seorang pejabat kesehatan di Washington, Amerika mengumumkan seorang pasien yang terinfeksi virus COVID-19 telah meninggal dunia. ${ }^{36}$ Hingga Indonesia terkena dampaknya sampai akhirnya keluarlah melalui Keputusan Presiden Republik Indonesia Nomor 12 Tahun 2020 tanggal 13 April 2020 Tentang Penetapan Bencana Nonalam Penyebaran Corona Virus Desease 2019 (COVID-19) Sebagai Bencana Nasional. Jelas COVID-19 adalah kejadian tidak terduga.

2. Adanya halangan yang menyebabkan suatu prestasi tidak mungkin dilaksanakan;

Suatu keadaan atau situasi dapat dikatakan sebagai force majeure apabila keadaan tersebut menghalangi debitur memenuhi prestasinya. Jika kita lihat

\footnotetext{
${ }^{35} \mathrm{Ibid}$

${ }^{36}$ Mela Arnani, Timeline Wabah Virus Corona, Terdeteksi pada Desember 2019 Hingga Jadi Pandemi Global, KOMPAS.com,
} 
COVID-19 ini termasuk kedalam force majeur relatif karena sifatnya yang sementara. Jadi, ketika COVID-19 sudah mereda, hilang, atau pemerintah mengumumkan bahwa COVID19 sudah bukanlah lagi sebagai bencana nonalam, maka debitur dapat melaksanakan kewajibannya atau memenuhi prestasinya sesuai dengan perjanjian yang telah ia buat sebelum COVID-19 terjadi.

3. Ketidakmampuan tersebut tidak disebabkan oleh kesalahan debitur;

Perjanjian kredit berdasarkan asas kepercayaan dan perlu adanya iktikad baik dari debitur untuk memenuhi kewajibannya dalam membayar utang berupa kredit. Dikatakan force majeure jika debitur tidak mampu memenuhi prestasi karena keasalahan debitur, namun dalam hal COVID-19 bukanlah keadaan yang dibuat oleh debitur sehingga COVID-19 bisa masuk kedalam unsur force majeure.

4. Ketidakmampuan tersebut tidak dapat dibebankan risiko kepada debitur.

COVID-19 adalah peristiwa dan kejadian yang tidak terduga yang mana diluar kendali debitur sehingga risiko pemenuhan prestasi tidak dapat dibebankan kepada debitur.

Pemerintah dengan ini telah melonggarkan keringan kredit debitur bank dengan cara restrukturisasi kredit melalui Peraturan Otoritas Jasa Keuangan Nomor 11 /POJK.03/2020 Tentang Stimulus Perekonomian Nasional Sebagai Kebijakan Countercyclical Dampak Penyebaran
Coronavirus Disease 2019 (POJK Restrukturisasi Kredit Bank).

Restrukturisasi kredit adalah upaya perbaikan yang dilakukan dalam kegiatan perkreditan terhadap debitur yang berpotensi mengalami kesulitan untuk memenuhi kewajibannya. ${ }^{37}$ Restrukturisasi kredit tersebut tidak menghilangkan kewajiban debitur bank $^{38}$ untuk membayar kredit kepada bank, namun adanya keringan berupa:

1. Penurunan suku bunga kredit;

2. Perpanjangan jangka waktu kredit;

3. Pengurangan tunggakan bunga kredit;

4. Pengurangan tunggakan pokok kredit;

5. Penambahan fasilitas kredit; dan/atau

6. Konversi kredit menjadi Penyertaan Modal Sementara.

Sesuai dengan prinsip kredit bank $^{39}$, kebijakan POJK Restrukturisasi Kredit Bank adalah sebagai berikut:

a. Penilaian kualitas kredit/pembiayaan/ penyediaan dana lain hanya berdasarkan ketepatan pembayaran pokok dan/atau bunga untuk kredit s.d Rp10 miliar.

b. Restrukturisasi dengan peningkatan kualitas kredit/pembiayaan menjadi lancar setelah direstrukturisasi. Ketentuan restrukturisasi ini dapat diterapkan Bank tanpa batasan plafon kredit.

c. Relaksasi berlaku untuk debitur Non-UMKM dan UMKM dan

\footnotetext{
37 Shifa Nurhaliza, Informasi Seputar Restrukturisasi Kredit Perbankan, IDX.com, ${ }^{38}$ Ibid

39 Munir Fuady dalam buku Nina Sri Imaniyati yang berjudul Pengantar Hukum Perbankan Indonesia (2010, hal.142-144)
} 
diberlakukan sampai dengan satu tahun setelah ditetapkan.

d. Mekanisme penerapan diserahkan sepenuhnya kepada kebijakan masing-masing bank dan disesuaikan dengan kapasitas membayar debitur.

e. Restrukturisasi

kredit/pembiayaan dilakukan sesuai peraturan OJK mengenai penilaian kualitas aset, antara lain dengan cara: penurunan suku bunga, perpanjangan jangka waktu, pengurangan tunggakan pokok, pengurangan tunggakan bunga, penambahan fasilitas kredit/pembiayaan, konversi kredit/pembiayaan menjadi Penyertaan Modal Sementara.

\section{Kesimpulan}

Dilihat dari unsur-unsur force majeur dalam Pasal 1244 dan 1245 KUHPerdata bahwa COVID-19 bisa dimasukkan kedalam force majeur yang bersifat relatif atau sementara karena pemerintah sudah menetapkan bahwa COVID-19 sebagai bencana nonalam.

Pemerintah dengan ini membantu meringankan beban debitur untuk memenuhi prestasinya yaitu dengan cara memberi kelonggaran kredit berupa restrukturisasi melalui Peraturan Otoritas Jasa Keuangan Nomor 11 /POJK.03/2020 Tentang Stimulus Perekonomian Nasional Sebagai Kebijakan Countercyclical Dampak Penyebaran Coronavirus Disease 2019. Harapannya adalah meningkatkan ketahanan bisnis debitur di tengah krisis akibat pandemi COVID-19.

\section{E. Daftar Pustaka}

Agtha, E. dan A.Novera. Keadaan Kahar Akibat COVID-19 dan Penerapannya dalam Perjanjian Kredit. Seminar Nasional AvoER XII 2020 Fakultas Teknik Universitas Sriwijaya. http://ejournal.ft.unsri.ac.id/index .php/AVoer/article/view/675, Diakses pada tanggal 25 Januari 2021.

Arnani, Mela. Timeline Wabah Virus Corona, Terdeteksi pada Desember 2019 Hingga Jadi Pandemi Global. KOMPAS.com. https://www.kompas.com/tren/rea $\mathrm{d} / 2020 / 03 / 12 / 113008565 /$ timelin e-wabah-virus-corona-terdeteksipada-desember-2019-hinggajadi?page $=$ all. $\quad$ Diakses pada tanggal 25 Januari 2021.

Badrulzaman, Mariam Darus et.al, Kompilasi Hukum Perikatan, Bandung: PT. Citra Aditya Bakti, 2001.

Badrulzaman, Mariam Darus. $K U H$ Perdata Buku III Hukum Perikatan dengan Penjelasan, Bandung: PT Alumni, 2011.

Djumhana, Muhamad. Hukum Perbankan di Indonesia, Bandung: Citra Aditya Bakti, 1996, cet. ke-2.

Fuady, Munir. Hukum Perkreditan Kontemporer, Bandung: Citra Aditya Bakti, 1996.

Ibrahim, Johny. Teori \& Metodologi Penelitian Hukum Normatif, Surabaya: Bayumedia Publishing,2007, cet. Ke-3.

Imaniyati, Neni Sri. Pengantar Hukum Perbankan Indonesia, Bandung: Refika Aditama, 2010.

Kitab Undang-Undang Hukum Perdata (Burgerlijk Wetboek), diterjemahkan oleh R. Subekti 
dan R. Tjitrosudibio, Jakarta: PT Pranadya Paramita, 2004, cet. ke34.

Konarski, Hubert. Force Majeuree and Hardship Clauses in Internasional Contractual Practice. No 4 of 2003 Int'l Bus. L. J. 405-428, 2003. https://www.researchgate.net/pub lication/284968473_Force_Majeu re_and_Hardship_Clauses_in_Int ernational_Contractual_Practice. Diakses pada tanggal 23 Januari 2021.

Kurniati, Dian. Kadin: 6,4 Juta Pekerja Dirumahkan atau Di-PHK Akibat Corona. DDTC.com. https://news.ddtc.co.id/kadin-64juta-pekerja-dirumahkan-atau-diphk-akibat-corona-24551.

Diakses pada tanggal 23 Januari 2021.

Mamudji, Sri et al. Metode Penelitian dan Penulisan Hukum, Jakarta: Badan Penerbit Fakultas Hukum Universitas Indonesia, 2006, cet. $\mathrm{Ke}-1$.

M. Sinaga, Syamsudin. Hukum Kepailitan Indonesia, Ciputat: PT Tatanusa, 2012 cet. ke-1.

Nurhaliza, Shifa. Informasi Seputar Restrukturisasi Kredit Perbankan. IDX.com. https://www.idxchannel.com/mar ket-news/foto/informasi-seputarrestrukturisasi-kredit-perbankan. diakses pada tanggal 20 Januari 2021

Otoritas Jasa Keuangan. https://www.ojk.go.id/id/kanal/pe rbankan/Pages/Suku-BungaDasar.aspx. Diakses pada tanggal 25 Januari.

Peraturan Presiden Nomor 16 Tahun 2018 Tentang Pengadaan Barang/Jasa Pemerintah,
Lembaran Negara Republik Indonesia (LNRI)Tahun 2018 Nomor 33.

Putri, Cantika Adinda. Sedihnya, Omzet UMKM Turun $30 \%$ di Masa Pandemi Covid-19. CNBCINDONESIA.com. https://www.cnbcindonesia.com/ news/20201215131853-4209208/sedihnya-omzet-umkmturun-30-di-masa-pandemi-covid19. Diakses pada tanggal 23 Januari 2021.

Sekertariat Kabinet Republik Indonesia. Pemerintah Berikan Subsidi Bunga UMKM dan Relaksasi Kredit Ultra Mikro. https://setkab.go.id/pemerintahberikan-subsidi-bunga-umkmdan-relaksasi-kredit-ultra-mikro/. Diakses pada tanggal 21 Januari 2021.

Soemadipradja, Rachmat S.S. Penjelasan Hukum Tentang Keadaan Memaksa, Jakarta: National Legal Reform Program, 2010.

Subekti, Pokok-Pokok Hukum Perdata, Jakarta: Intermasa, 2003.

Thomson Reuters. https://uk.practicallaw.thomsonre uters.com/3-107-

5776?transitionType $=$ Default\&co ntextData $=$ (sc.Default $) \&$ firstPage $=$ true. Diakses pada tanggal 23 Januari 2021.

Undang-Undang Nomor 2 Tahun 2017 Tentang Jasa Konstruksi, Lembaran Negara Republik Indonesia (LNRI) Tahun 2017 No. 11. Tambahan Lembaran Negara (TLN) No. 6018

Undang-Undang Nomor 37 Tahun 2004 Tentang Kepailitan dan Penundaan Kewajiban Pembayaran Utang, Lembaran 
IBLAM LAW REVIEW

SEKOLAH TINGGI ILMU HUKUM IBLAM

Vol 1 No 1 2021, Hal 163-183

Negara Republik Indonesia (LNRI) Tahun 2004 Nomor 131, dan Tambahan Lemabara Negara (TLN) No. 4443.

World Health Organization.

https://covid19.who.int/region/se

aro/country/id. Diakses pada tanggal 23 Januari 2020. 